\title{
Surgical treatment of bicuspid aortic valve disease
}

\author{
Ivan Kravchenko ${ }^{1 *}$, VI Kravchenko ${ }^{1}$, LL Sytar ${ }^{1}$, OV Pantas $^{1}$, SO Dykuha², MY Atamanyuk ${ }^{2}$, GV Knyshov $^{3}$ \\ From 23rd World Congress of the World Society of Cardio-Thoracic Surgeons \\ Split, Croatia. 12-15 September 2013
}

\section{Background}

Congenital bicuspid aortic valve (BAV) - one of the most frequent cardiovascular lesions, with prevalence up to $2.4 \%$. About a half of them need the surgical treatment throughout life.

\section{Methods}

1217 patients with BAV were treated in the Institute during 2003-2012. There were 902 (74.1\%) males. Patients age ranged from 3 days to 76 years, mean 50.2 $\pm 9,8$ years. Aneurysm of ascending aorta took place in $380(31.2 \%)$ pts, $39(10,3 \%)$ of them admitted with dissection. We use: balloon valvuloplasty in $82(8.1 \%)$ patients. Different operative interventions were fulfilled to the rest :1135 $(93,3 \%)$ pts: open aortic valvotomy $64(5,3 \%)$, aortic valve replacement (AVR) - 691 (56.8\%), AVR with ascending aorta banding - in $83(6,8 \%)$, Robicsek operation - 121 (10.0\%), Bentall's operation $162(13.3 \%)$, Wheat's operation $-9(0.7 \%)$, supracoronary aortic grafting with AV resurpension - $3(0.2 \%)$, David's operation $-2(0.2 \%) ; 51(4.2 \%)$ patients with BAV treated of coarctation of the aorta earlier.

\section{Results}

Total 30-day mortality composed $2.3 \%$ (26 pts). Death causes: acute heart failure - in $13(1,1 \%)$; respiratory insufficiency - in $4(0.3 \%)$, bleeding - in $2(0.2 \%)$, multiorgan failure - in $4(0,3 \%)$, cerebral injury - in $3(0.2 \%)$. Remote results were studied in 1110 (93.7\%) discharged

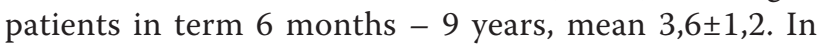
mostly $-84.4 \%$ and $10.9 \%$ it was good and satisfactory. Unsatisfactory in $23(2.0 \%)$, died in remote terms 27 $(2,4 \%)$ pts. Redo operation were performed in $14(2.1 \%)$ pts after AVR in a reason of aneurysm forming.

\footnotetext{
* Correspondence: vicmd@ukr.net

${ }^{1}$ Department of Aortic Surgery, M. Amosov National Institute of CVS NAMS Ukraine, Kyiv, Ukraine

Full list of author information is available at the end of the article
}

\section{Conclusion}

Bicuspid aortic valve disease characterized by injury of aortic valve and ascending aorta. Aneurysm forming were observed in $380(31.2 \%)$ patients with BAV, among them in $39(10.3 \%)$ with dissection. Redo operations in a reason of aneurysm forming needs $2.1 \%$ in the elective AVR group. Operative treatment of patients with BAV permitted to obtain good and satisfactory remote results in $84.4 \%$ and $10.9 \%$ cases.

\section{Authors' details}

${ }^{1}$ Department of Aortic Surgery, M. Amosov National Institute of CVS NAMS Ukraine, Kyiv, Ukraine. ${ }^{2}$ Department of Congenital Heart Liason, M. Amosov National Institute of CVS NAMS Ukraine, Kyiv, Ukraine. ${ }^{3} \mathrm{M}$. Amosov National Institute of CVS NAMS Ukraine, Kyiv, Ukraine.

Published: 11 September 2013

\section{doi:10.1186/1749-8090-8-S1-P7}

Cite this article as: Kravchenko et al:: Surgical treatment of bicuspid aortic valve disease. Journal of Cardiothoracic Surgery 2013 8(Suppl 1):P7.

\section{Submit your next manuscript to BioMed Central and take full advantage of:}

- Convenient online submission

- Thorough peer review

- No space constraints or color figure charges

- Immediate publication on acceptance

- Inclusion in PubMed, CAS, Scopus and Google Scholar

- Research which is freely available for redistribution

Submit your manuscript at www.biomedcentral.com/submit
C Bïomed Central

\section{Ciomed Central}

